\title{
Similarity between predicted and obtained oxygen consumption during incremental cardiopulmonary exercise test in healthy men and chronic heart failure patients
}

\author{
Similaridade entre o consumo de oxigênio obtido e previsto durante teste de exercicio \\ cardiopulmonar incremental de homens saudáveis ou com insuficiência cardiaca crônica \\ Similitud entre el consumo de oxígeno predicho y obtenido durante la prueba de esfuerzo \\ cardiopulmonar incremental de hombres sanos o con insuficiencia cardiaca crónica \\ Rafael Santiago Floriano', Alexandre Fenley², Daniel Sobral Teixeira ${ }^{3}$, Leonardo da Costa Silva4, \\ Hugo Valverde Reis ${ }^{5}$, Audrey Borghi-Silva ${ }^{6}$, Michel Silva Reis ${ }^{7}$
}

\begin{abstract}
I Cardiopulmonary exercise testing (CPX) is a noninvasive method for assessing physiological changes during physical exercise. Functional capacity has been evaluated using prediction equations. However, this evaluation method may yield different outcomes when applied to a healthy male population and patients with chronic heart failure (HF). This study aimed to compare the estimated and obtained values of oxygen consumption $\left(\mathrm{VO}_{2}\right)$ during $\mathrm{CPX}$ both at the ventilatory anaerobic threshold (VAT) and at peak exercise for healthy men and HF patients. For that, 56 men were divided into 3 groups: (1) 18 young and healthy (YG) (27 \pm 6.01 years); (2) 14 healthy older adults (OG) (61 \pm 6.3 years); and (3) 24 chronic HF patients (HFG) ( $53 \pm 13.6$ years). CPX in cycle ergometer was administered to all individuals for determining $\mathrm{VO}_{2}$ at the VAT and peak exercise. Then, $\mathrm{VO}_{2}$ was estimated at the two moments using a prediction equation, and estimated values were compared to those obtained. Estimated $\mathrm{VO}_{2}$ was significantly higher than obtained VO2 in OG (16.9 \pm 1.8 vs. $13.1 \pm 2.1 \mathrm{~mL} / \mathrm{kg} / \mathrm{min})$ and HFG $(12 \pm 6.9$ vs. $8.7 \pm 2.5 \mathrm{~mL} / \mathrm{kg} / \mathrm{min})$. We found no difference
\end{abstract}

between estimated and obtained $\mathrm{VO}_{2}$ for the $\mathrm{YG}(22,6 \pm 5,5 \mathrm{vs}$. $23,1 \pm 8,7 \mathrm{~mL} / \mathrm{kg} / \mathrm{min})$. The prediction equation overestimated $\mathrm{VO}_{2}$ values for older adults and HF patients. However, the YG obtained similar values than those estimated.

Keywords I Exercise Test; Oxygen Consumption; Heart Failure, Anaerobic Threshold.

RESUMO I O teste exercício cardiopulmonar (CPX) é uma metodologia não invasiva de avaliação global da integridade dos ajustes fisiológicos durante o exercício físico. Como alternativa, a avaliação da capacidade funcional foi realizada por meio de fórmulas preditivas. No entanto, esse método de avaliação pode ter resultados diferentes quando usado em uma população de homens saudáveis e pacientes com insuficiência cardíaca (IC) crônica. Compararam-se os valores de consumo de oxigênio $\left(\mathrm{VO}_{2}\right)$ obtidos e estimados durante o CPX no limiar anaeróbio ventilatório ( $L A V$ ) e no pico do exercício para homens saudáveis e pacientes com IC crônica. Cinquenta e seis homens foram divididos em 3

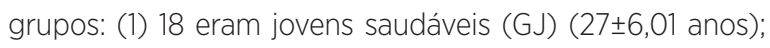

This work was displayed as a single presentation at the XXXV Congress of the Sociedade de cardiologia do Estado do Rio de Janeiro (SOCERJ 2016);

This work was displayed as an e-poster at the XXXVIII Congress of the Sociedade de cardiologia do Estado de São Paulo (SOCESP 2017) This work was displayed as a single presentation at the XLIV Congress of the Sociedade Brasileira de Cirurgia Cardiovascular, at Rio de Janeiro state (SBCCV 2017)

Universidade Federal do Rio de Janeiro (UFRJ) - Rio de Janeiro (RJ), Brazil. E-mail: rafael_floriano@hotmail.com. Orcid: 0000-0001-7170-5209 2Universidade Federal do Rio de Janeiro (UFRJ) - Rio de Janeiro (RJ), Brazil. E-mail: alefenley@gmail.com. Orcid: 0000-0002-8715-8171 ${ }^{3}$ Universidade Federal do Rio de Janeiro (UFRJ) - Rio de Janeiro (RJ), Brazil. E-mail: drdanielatm@gmail.com. Orcid: 0000-0001-5960-0447 ${ }^{4}$ Universidade Federal do Rio de Janeiro (UFRJ) -Rio de Janeiro (RJ), Brazil. E-mail: leocostha@globo.com. Orcid: 0000-0002-5858-4200 5Universidade Federal do Rio de Janeiro (UFRJ) - Rio de Janeiro (RJ), Brazil. E-mail: hugovalverdereis@hotmail.com. Orcid: 0000-0002-6415-7539 6Universidade Federal de São Carlos (UFSCar) - São Carlos (SP), Brazil. E-mail: audrey@ufscar.br. Orcid: 0000-0002-3891-6941 ${ }^{7}$ Universidade Federal do Rio de Janeiro (UFRJ) - Rio de Janeiro (RJ), Brazil. E-mail: msreis@hucff.ufrj.br. Orcid: 0000-0002-3817-0529 


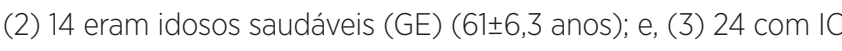
crônica (HFG) $(53 \pm 13,6$ anos). Todos foram submetidos ao CPX em cicloergômetro para determinação do $\mathrm{VO}_{2}$ no LAV e no pico do exercício. Posteriormente, a estimativa do $\mathrm{VO}_{2}$ foi realizada na potência do LA e no pico do exercício por meio de uma fórmula de predição para exercício físico em cicloergômetro. Os valores de $\mathrm{VO}_{2}$ obtidos e a carga estimada foram comparados. $\mathrm{O} \mathrm{VO}_{2}$ estimado foi significativamente maior que o $\mathrm{VO}_{2}$ obtido no $\mathrm{GE}$ e no HFG (16,9 $\pm 1,8$ vs. $13,1 \pm 2,1 \mathrm{~mL} / \mathrm{kg} / \mathrm{min}$ e $12 \pm 6,9$ vs. $8,7 \pm 2,5 \mathrm{~mL} / \mathrm{kg} /$ min, respectivamente). Por fim, não houve diferença nos valores de $\mathrm{VO}_{2}$ estimados e obtidos para o GJ $(22,6 \pm 5,5$ vs. $23,1 \pm 8,7 \mathrm{~mL} /$ $\mathrm{kg} / \mathrm{min}$, respectivamente). A fórmula de predição superestimou os valores de $\mathrm{VO}_{2}$ para idosos e pacientes com IC crônica. Porém, no GJ os valores de $\mathrm{VO}_{2}$ se mostraram semelhantes para a fórmula de predição e o obtido durante o CPX em cicloergômetro.

Descritores | Teste de Esforço; Consumo de Oxigênio; Insuficiência Cardíaca; Limiar Anabólico.

RESUMEN I La prueba de ejercicio cardiopulmonar (CPX) es una metodología no invasiva para evaluar la integridad global de los ajustes fisiológicos durante la práctica de ejercicio físico. Se realizó como alternativa la evaluación de la capacidad funcional por medio de fórmulas predictivas. Sin embargo, este método de evaluación puede presentar resultados distintos cuando se utiliza en una población de hombres sanos y de pacientes con insuficiencia cardíaca crónica (IC). Se compararon los valores de consumo de oxígeno $\left(\mathrm{VO}_{2}\right)$ obtenido y estimado durante la CPX en el umbral anaeróbico ventilatorio (LAV) y en la cima del ejercicio para hombres sanos y pacientes con IC crónica. Se dividieron a 56 hombres en 3 grupos:

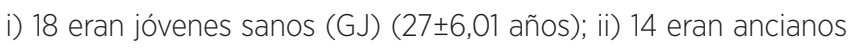

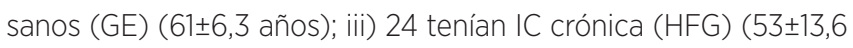
años). Todos se sometieron a CPX en un cicloergómetro para determinar el $\mathrm{VO}_{2}$ en LAV y en la cima del ejercicio. Posteriormente, la estimación de $\mathrm{VO}_{2}$ se realizó sobre la potencia de LA y en la cima del ejercicio mediante una fórmula predictiva del ejercicio físico en un cicloergómetro. Los valores de $\mathrm{VO}_{2}$ obtenidos y la carga estimada se compararon. El $\mathrm{VO}_{2}$ estimado fue significativamente mayor que el $\mathrm{VO}_{2}$ obtenido en GE y HFG $(16,9 \pm 1,8 \mathrm{vs} .13,1 \pm 2,1 \mathrm{ml} / \mathrm{kg} / \mathrm{min}$ y $12 \pm 6,9$ vs. $8,7 \pm 2,5 \mathrm{ml} / \mathrm{kg} / \mathrm{min}$, respectivamente). No hubo diferencias en los valores de $\mathrm{VO}_{2}$ estimado y obtenido para el GJ $(22,6 \pm 5,5$ vs. $23,1 \pm 8,7 \mathrm{ml} / \mathrm{kg} / \mathrm{min}$, respectivamente). La fórmula predictiva sobrestimó los valores de $\mathrm{VO}_{2}$ para ancianos y pacientes con IC crónica. Sin embargo, en GJ los valores de $\mathrm{VO}_{2}$ fueron similares para la fórmula predictiva y la obtenida durante el CPX en cicloergómetro. Palabras clave I Prueba de Esfuerzo; Consumo de Oxígeno; Insuficiencia Cardíaca; Umbral Anabólico.

\section{INTRODUCTION}

The cardiopulmonary exercise testing (CPX) is a noninvasive method for assessing the integrity of cardiovascular, respiratory, muscular, peripheral, neurophysiological, humoral, and hematological changes in the human body during physical exercise ${ }^{1-3}$. CPX is also useful in determining functional capacity by providing the two most common functional limitation indexes: the peak oxygen consumption $\left(\mathrm{VO}_{2}\right.$ peak $)$ - the peak $\mathrm{VO}_{2}$ attained at maximum-effort - or maximal oxygen consumption $\left(\mathrm{VO}_{2} \max \right)-\mathrm{VO}_{2}$ plateau at maximum exhaustion; and the ventilatory anaerobic threshold (VAT) at submaximal or maximal exercise ${ }^{1,4,5}$

$\mathrm{VO}_{2}$ peak and VAT during exercise may function as a prognostic marker and determine individuals' functional capacity ${ }^{6}$. However, the standard evaluation method may fail in identifying VAT in chronic heart failure (HF) patients (approximately 10\% of the cases), as it would imply a worse prognosis ${ }^{7}$. These markers may also contribute to exercises prescription ${ }^{1,3,8}$.
Despite being the gold standard measure for determining functional capacity, $\mathrm{VO}_{2}$ max or $\mathrm{VO}_{2}$ peak, and $\mathrm{VAT}^{1,3,8}$, the CPX requires a very expensive equipment, a team with at least three well-trained researchers, and a specialized laboratory for its proper operation ${ }^{1,8-10}$. Thus, few places have all the necessary technological apparatus for conducting CPX and are specialized in this exam ${ }^{10}$, such as professional soccer clubs and the research labs of few universities.

Functional capacity is indirectly evaluated using prediction equations with correction for the anthropometric characteristics and the executed workload ${ }^{11-13}$. Our results corroborate those reported by Almeida et al. Prediction equations enable us to estimate $\mathrm{VO}_{2}$ at VAT and at the peak exercise, so that it is important to discuss the advantages of this method when compared with the $\mathrm{CPX}^{8}$. Prediction equations are more affordable, practical, and fast in determining $\mathrm{VO}_{2}$. The literature is incipient regarding the similarity between results obtained by prediction (indirect) and by the gold standard in a cycle ergometer (direct). Such similarity would add value to 
the use of the indirect method for obtaining $\mathrm{VO}_{2}$ at VAT and peak exercise, or even validate the similarity between the estimated and obtained $\mathrm{VO}_{2}$. In this context, this study aim to evaluate whether $\mathrm{VO}_{2}$ values at VAT and peak exercise estimated by prediction equations are similar to those established by the gold standard in a cycle ergometer for healthy young and older adults and chronic HF patients.

\section{METHODOLOGY}

Healthy young and older male adults, and patients with chronic heart failure (HF) were evaluated. Groups formed by older adults and chronic HF patients were selected by convenience sampling. All participants agreed to participate in this research. The cardiopulmonary exercise testing $(\mathrm{CPX})$ was performed on cycle ergometer using a ramp protocol.

\section{Study design and subjects}

This is an observational cross-sectional study conducted with male participants who met the following inclusion criteria: 1) young group (YG) - aged 19-36 years and considered healthy according to clinical evaluation; 2) older group (OG) - aged 60-91 years and considered healthy according to clinical evaluation; and 3) chronic HF group (HFG) - presenting a history of stable chronic $\mathrm{HF}$ caused by left ventricular systolic dysfunction during the last 6 months (left ventricular ejection fraction <45\%), clinical stability in the last 3 months, and no history of angina or coexistence of pulmonary disease.

Chronic HF patients with clinical or functional evidence of chronic obstructive pulmonary disease $\left(\mathrm{FEV}_{1} / \mathrm{FVC}<70 \%\right)^{14}$, exercise-induced asthma, significant angina or arrhythmias, and myocardial infarction in the past 6 months, as well as those who joined a cardiac rehabilitation program in the past year were excluded. As for the YG and OG, volunteers with a history of cardiovascular, respiratory, muscular, orthopedic, neurological, metabolic, and immunologic disease, or with clinical or functional evidence of chronic obstructive pulmonary disease $\left(\mathrm{FEV}_{1} / \mathrm{FVC}<70 \%\right)^{14}$ were excluded.

All volunteers underwent clinical evaluation, biochemical exams, and electrocardiography. Pulmonary function testing (spirometry) was performed using the Vitalograph ${ }^{\circledR}$ spirometer (Hand-Held 2021 instrument, Ennis, Ireland) to measure the forced vital capacity (FVC) to determine the forced expiratory volume $\left(\mathrm{FEV}_{1}\right)$ and $\mathrm{FEV}_{1} / \mathrm{FVC}$ ratio $^{15}$. We employed values reported by Knudson et al. ${ }^{16}$ as reference for conditions and technical procedures, expressed in body temperature pressure standard (BTPS). Acceptability and reproducibility criteria were defined according to the American Thoracic Society (1995) recommendations. HF was assessed according to the New York Heart Association (NYHA) classification. All patients with chronic HF were optimized with betablocker therapy. This work was approved by the Ethics Committee of the Federal University of São Carlos, SP, Brazil (protocol 238/06) and the Federal University of Rio de Janeiro, Rio de Janeiro, RJ, Brazil (protocol CAAE 47813415.8.0000.5257). All volunteers agreed to participate by signing the informed consent form, and subjects' privacy and data confidentiality were fully guaranteed during all stages of the study.

\section{Experimental protocols}

The recruited volunteers underwent the following steps:

\section{Physical evaluation}

All volunteers underwent a detailed physical examination that collected personal data, anthropometric data, vitals, and nutritional status (body mass index-BMI).

\section{Maximum or symptom-limited cardiopulmonary exercise test}

The CPX was performed on cycle ergometer (Inbramed, Porto Alegre, Brazil) using a ramp protocol. Patients initially got a 3-minute rest, sitting on the cycle ergometer; then, they started the 3-minute warm-up with a pedal load ranging from $1 \mathrm{~W}$ (applied to $O G$ and HFG) to $15 \mathrm{~W}$ (applied to YG). The physical exercise protocol initiated after this stage, adding 10 to $25 \mathrm{~W}$ load every minute until physical exhaustion - when the volunteer was unable to keep cycling under the imposed load. Volunteers were instructed to maintain a 60-70rpm cadence throughout the $\mathrm{CPX}^{17}$.

An evaluator was responsible for controlling load distribution using the ergometer. After completion, participants underwent a 3-minute post-test recovery period at $25 \mathrm{~W}$ load, followed by a 2 -minute rest, where they remained seated on the cycle. The BORG scale was collected every 3 minutes until load interruption, and ventilatory and metabolic variables and heart 
rate $(\mathrm{HR})$ were measured during the entire test period. Peripheral oxygen saturation $\left(\mathrm{SpO} 2-\right.$ Onyx $\left.9500^{\circledR}\right)$ and ECG electrocardiogram (Wincardio USB) in different leads - MC5, DII, DIII, aVR, aVL and aVF, and V1 to V6 - were continuously monitored throughout the experimental procedure. A team of physiotherapist and physician researchers conducted the tests, attentive to signs and symptoms of inadequate response to exercise. Ventilatory and metabolic variables were obtained using a computerized ergospirometric system $\left(\mathrm{VO}_{2000}\right.$ - Portable Medical Graphics Corporation $\left.{ }^{\circledR}\right)$.

Tidal volume was obtained using a high-flow pitot tube pneumotachometer connected to the $\mathrm{VO}_{2000}$ system and coupled to a face mask properly adjusted to the volunteer's face size, avoiding air leakage. After placing the mask, the volunteer was instructed not to communicate verbally, using only hand gestures to inform perceived exertion according to the modified Borg rating scale (CR-10) every 3 minutes, or to signal protocol interruption. The test was initiated when participants' respiratory quotient $(\mathrm{R})$ was 0.8 . The equipment provides real-time values of $\mathrm{VO}_{2}, \mathrm{VCO}_{2}$, pulmonary ventilation ( $\left.\mathrm{LV}\right), \mathrm{HR}$ and $\mathrm{SpO}_{2}$. $\mathrm{O}_{2}$ ventilatory equivalents $\left(\mathrm{VE} / \mathrm{VO}_{2}\right), \mathrm{VCO}_{2}$ ventilatory equivalents $\left(\mathrm{VE} / \mathrm{VCO}_{2}\right)$, metabolic variables, respiratory exchange ratio (RER), fractions at end-tidal $\mathrm{O}_{2}$ expiration $\left(\mathrm{FETO}_{2}\right)$, partial fractions $\left(\mathrm{FETCO}_{2}\right)$, tidal volume (VC) and respiratory rate (RR), were also calculated. The test was interrupted when ${ }^{18}$ participants were unable to maintain the cadence of 60-70 rpm; presented profuse sweating, complex arrhythmias, angina, pallor, maximum $\mathrm{HR}$, systolic blood pressure $(\mathrm{SBP})>220 \mathrm{mmHg}$, peripheral desaturation less than 90\%, dizziness, and cyanosis.

\section{Using the prediction equation}

After analyzing CPX scores, the data were tabulated in Microsoft Office Excel ${ }^{\circledR}$ for Windows XP ${ }^{\circledR}$ (USA) and grouped so that we could apply Astrand's prediction equation ${ }^{19}$ for VAT and $\mathrm{VO}_{2}$, considering:

$\mathrm{VO}_{2} \mathrm{~mL} / \mathrm{kg} \cdot \mathrm{min}^{-1}=\left(\right.$ workload-watts $\left.{ }^{*} 12\right)+300 /$ body mass (kg). Then, $\mathrm{VO}_{2}$ values at VAT and peak were compared between the two models to verify similarity.

\section{Statistical analysis}

The SigmaPlot statistical software (version 11.0 for Windows/2008) was used for data processing. The ShapiroWilk and Levene's tests were used to verify data normality and homogeneity of variances. The two-way repeated measures analyses of variance (two-way ANOVA) and Holm-Sidak post-hoc were used to compare YG, OG, and $\mathrm{HFG}$ regarding the obtained and estimated $\mathrm{VO}_{2}$. All measures were expressed as mean \pm standard deviation (SD). The significance level was 5\% ( $\mathrm{p}<0.05)$.

\section{RESULTS}

All volunteers underwent the cardiopulmonary exercise testing (CPX) on cycle ergometer to determine oxygen consumption $\left(\mathrm{VO}_{2}\right)$ at the ventilatory anaerobic threshold (VAT) and at exercise peak. Then, we estimated $\mathrm{VO}_{2}$ for the same moments using a prediction equation. No volunteer was excluded from the survey after data collection, as described in Figure 1.

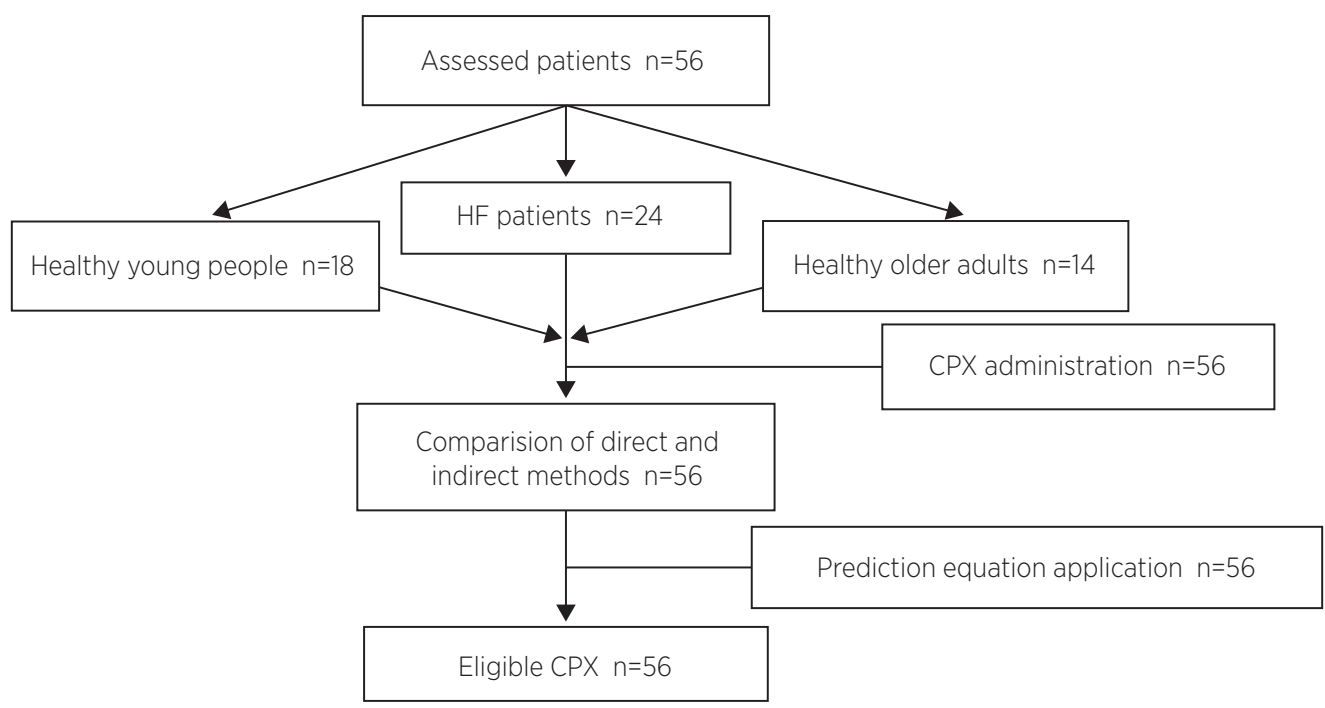

Figure 1. Flowchart describing patients selection at each stage of the study 
Table 1 shows the demographic and anthropometric data of the study volunteers. We found volunteers in the older group (OG) to present similar weight and height, without indication of obesity according to the body mass index (BMI). Left ventricular ejection fraction $(\mathrm{LVEF})$ in the heart failure group (HFG) was classified as moderate to severe according to the New York Heart Association (NYHA) in classes II and III.

Table 1. Anthropometric data and clinical characteristics of the study population

\begin{tabular}{|c|c|c|c|}
\hline Variables & $Y G(n=18)$ & OG $(n=14)$ & HFG $(n=24)$ \\
\hline Age (years) & $27.1 \pm 6.0$ & $61.4 \pm 6.3$ & $53.1 \pm 13.6$ \\
\hline Height (cm) & $170.1 \pm 0.1$ & $171.0 \pm 0.1$ & $169.0 \pm 7.0$ \\
\hline Weight (kg) & $76.2 \pm 11.0$ & $75.0 \pm 6.3$ & $76.3 \pm 12.8$ \\
\hline BMI $\left(\mathrm{kg} / \mathrm{m}^{2}\right)$ & $24.9 \pm 3.2$ & $24.3 \pm 3.0$ & $26.5 \pm 3.8$ \\
\hline FEVE & 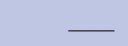 & $\longrightarrow$ & $30.0 \pm 7.8$ \\
\hline \multicolumn{4}{|l|}{ Functional status } \\
\hline NYHA II/III & - & - & $9 / 15$ \\
\hline \multicolumn{4}{|l|}{ CPX } \\
\hline $\mathrm{VO}_{2} \mathrm{AT}(\mathrm{L} / \mathrm{min})$ & $1.8 \pm 0.6$ & $1.0 \pm 0.2$ & $0.65 \pm 0.19$ \\
\hline $\mathrm{VO}_{2} \mathrm{AT}(\mathrm{mL} / \mathrm{kg} / \mathrm{min})$ & $23.1 \pm 8.8$ & $13.1 \pm 2.2$ & $8.7 \pm 2.5$ \\
\hline $\mathrm{VO}_{2}$ peak $(\mathrm{mL} / \mathrm{min})$ & $2.9 \pm 0.9$ & $1.7 \pm 0.3$ & $1.1 \pm 0.3$ \\
\hline $\mathrm{VO}_{2}$ peak $(\mathrm{mL} / \mathrm{kg} / \mathrm{min})$ & $37.1 \pm 11.9$ & $21.8 \pm 3.4$ & $15.1 \pm 4.1$ \\
\hline $\operatorname{VE}(\mathrm{L} / \mathrm{min})$ & $32.1 \pm 9.9$ & $30.3 \pm 6.3$ & $51.7 \pm 12.9$ \\
\hline \multicolumn{4}{|l|}{ Spirometry } \\
\hline $\operatorname{VEF}_{1}$ (\% estimated) & $98.6 \pm 8.0$ & $99.6 \pm 9.4$ & $80.3 \pm 8.6$ \\
\hline$V E F_{1} / F V C$ & $96.7 \pm 5.4$ & $94.4 \pm 5.8$ & $82.0 \pm 4.2$ \\
\hline FVC(\% estimated) & $99.0 \pm 8.8$ & & \\
\hline \multicolumn{4}{|l|}{ Medications ( $n$ ) } \\
\hline Diuretics & - & - & 14 \\
\hline Digitalis & - & - & 9 \\
\hline$\beta$-blockers & - & - & 24 \\
\hline Inhibitor-ECA & - & + & 15 \\
\hline
\end{tabular}

Values expressed as mean \pm SD. -> BMI: body mass index; NYHA: New York Heart Association; CPX: cardiopulmonary exercise testing; $\mathrm{VO}_{2} \mathrm{VAT}$ : oxygen consumption at ventilatory anaerobic threshold; VO2peak: oxygen consumption at exercise peak; FEV1: forced expiratory volume in the first second; FVC: forced vital capacity; YG: young group; OG: older group; HFG: heart failure group.

After follow-up and evaluation of the volunteers, we found no statistical difference between values estimated by the prediction equation and obtained by CPX regarding $\mathrm{VO}_{2}$ at VAT and exercise peak in the YG. However, the prediction equation overestimated $\mathrm{VO}_{2}$ values for the OG and HFG (Figures 2 and 3).

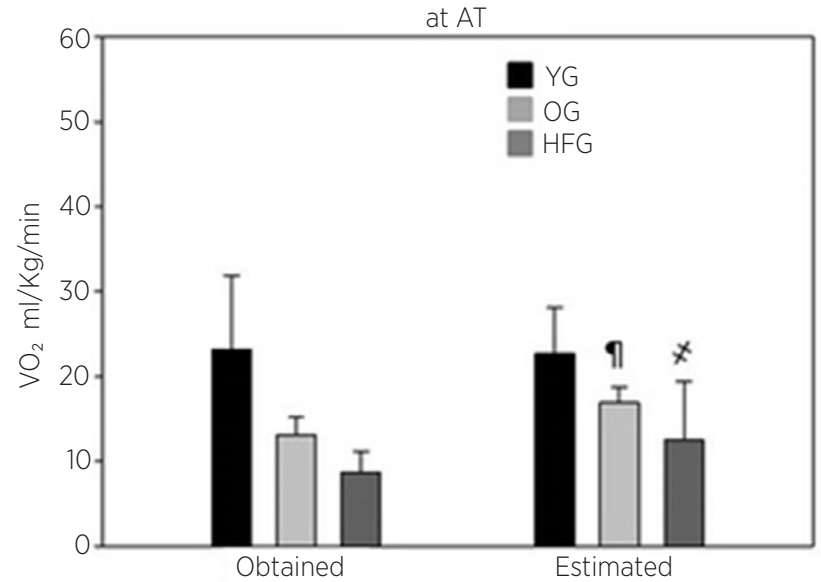

Figure 2. Estimated and obtained oxygen consumption $\left(\mathrm{VO}_{2}\right)$ of the study groups at the ventilatory anaerobic threshold (VAT). Older adults estimated vs. obtained, $\mathrm{p}<0.001 ; \neq$ chronic $\mathrm{HF}$ patients estimated vs. obtained, $\mathrm{p}<0.001$. YG: young group; EG: older group; and HFG: heart failure group.

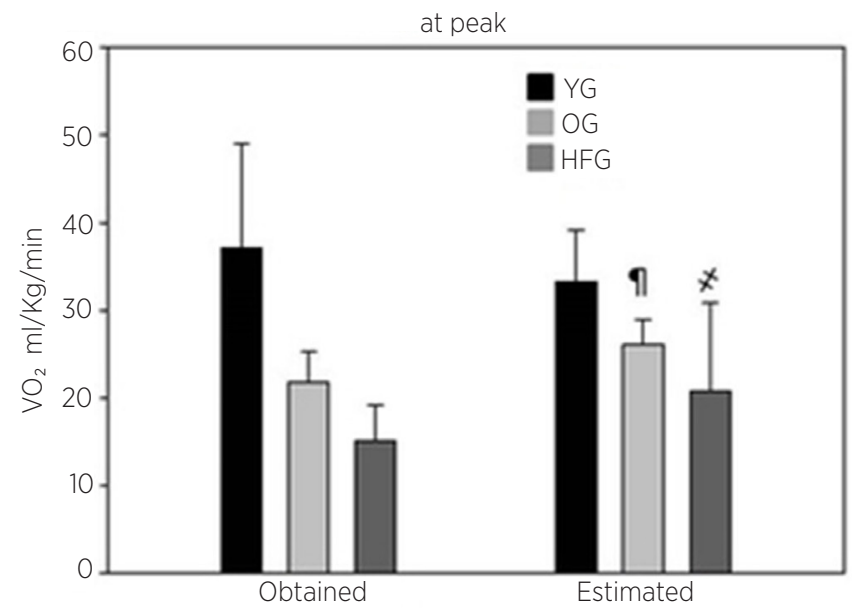

Figure 3. Estimated and obtained oxygen consumption $\left(\mathrm{VO}_{2}\right)$ of the study groups at exercise peak.

Older adults estimated vs. obtained, $p<0.001 ; \neq$ chronic HF patients estimated vs. obtained, $p<0.001$. YG: young group; OG: older group; and HFG: heart failure group

\section{DISCUSSION}

Our main findings suggest that the prediction equation proposed by Cooper et al. ${ }^{19}$ for cycle ergometer successfully obtained oxygen consumption $\left(\mathrm{VO}_{2}\right)$ at ventilatory anaerobic threshold (VAT) and exercise peak when applied to a young population, showing no significant statistical difference when compared to the gold standard (CPX). However, the same does not apply for older adults and chronic heart failure (HF) patients evaluated in this study.

In 2015, Costa et al. ${ }^{20}$ analyzed the level of agreement between oxygen consumption rate at no-load CPX and $\mathrm{VO}_{2}$ peak in an incremental cycle ergometer protocol within two groups: the GS - formed by apparently 
healthy sedentary individuals with mean age of $47 \pm$ $4(\mathrm{n}=12)$; and HFG - volunteers with coronary artery disease with mean age of $57 \pm 8(n=16)$. The authors verified $\mathrm{VO}_{2}$ by comparing the value estimated by the prediction equation proposed by Wasserman et al. ${ }^{2}\left[\mathrm{VO}_{2}\right.$ without load $(\mathrm{mL} / \mathrm{min})=150+(6 \times$ weight in $\mathrm{kg})$; and $\mathrm{VO}_{2}$ peak $(\mathrm{mL} / \mathrm{min}$ ) (height in $\mathrm{cm}$ and age in years) $\times 20$; $\operatorname{Ramp}(\mathrm{W} / \mathrm{min})=\mathrm{VO}_{2}$ peak $-\mathrm{VO}_{2}$ without load/100] with the $\mathrm{VO}_{2}$ directly obtained using the ergospirometry system. The HFG showed a difference between estimated and obtained $\mathrm{VO}_{2}$ at no-load CPX. Their findings are consistent with ours regarding the overestimated $\mathrm{VO}_{2}$ at exercise peak (32.5\%) for healthy older volunteers and chronic HF older patients in relation to the obtained $\mathrm{VO}_{2}$ for the same load peak (20\%).

Debeaumont, et al. ${ }^{21}$ conducted a research with a study population quite different from ours: the authors employed four prediction equations (Riddle, Hansen, Wasserman, and Gläser) to estimate peak $\mathrm{VO}_{2}$ in obese patients with metabolic syndrome (51 women and 24 men) ${ }^{21}$ and compared the estimated values with those obtained by CPX on the cycle ergometer. Multiple regression analysis (in which oxygen consumption was normalized by lean mass) was used to improve equation accuracy for this population. The authors found the predictive methods established by Wasserman et al. ${ }^{2}$ to validly predict peak $\mathrm{VO}_{2}$ in obese patients with metabolic syndrome. However, in our study, prediction accuracy was low for both methods. The prediction equation for $\mathrm{VO}_{2} \mathrm{AT}$ and $\mathrm{VO}_{2}$ max proposed by Cooper et al. ${ }^{19}$ was unable to predict these markers in healthy older individuals and those with chronic HF.

Koutlianos et al. ${ }^{12}$ evaluated $\mathrm{VO}_{2} \max$ indirect estimation using the American college of sports medicine (ACSM) prediction equation with the Bruce protocol in athletes of different sports specializations (basketball $n=13$, soccer $n=15$, riders $n=7$, volleyball $n=7$, body-building $n=4$, weightlifting $n=3$, wrestling $n=3$ and taekwondo $n=3$ ), and compared the results with those obtained by the direct method for developing a predictive regression model of $\mathrm{VO}_{2} \mathrm{max}$ in athletes. For that, 55 male and female athletes of national and international level $(28.3 \pm 5.6$ years) underwent CPX with ergospirometer for direct measurement. Three equations were used to indirectly estimate $\mathrm{VO}_{2}$ max: a) $\mathrm{VO}_{2} \max =(0.2 \times$ velocity $)+(0.9 \times$ velocit $\mathrm{y} \times$ slope $)+3.5$ (ACSM equation for running); $\mathrm{b}$ ) regression analysis model (it is important to verify whether two or more variables are somehow related, which must be expressed through a mathematical model; this model is called regression, and it helps understanding how certain variables affect other variables. That is, it verifies how a variable behavior influences the behavior of another); and c) stepwise regression (modified forward selection, whereby all variables are previously tested for their partial F-statistics at each step. A variable added to the model in the previous step may be redundant due to its relationship with other variables, and it is excluded when its partial F-statistic is less than $\mathrm{F}_{\text {out }}$. Age, BMI, velocity, slope, and exercise duration were used as independent variables. The $\mathrm{VO}_{2}$ max equation was developed based on the regression analysis using the regression $\operatorname{model}(\mathrm{mL} / \mathrm{kg} / \mathrm{min})=58,443-$

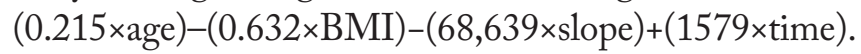
The values estimated by these regression models were not significantly different from those obtained $(\mathrm{p}<0.05)$. The $\mathrm{VO}_{2}$ max estimated by the ACSM's equation for runners overestimated the values obtained by the direct method (14.6\% with $\mathrm{p}<0.05)$. Thus, the authors concluded that the ACSM's equation for runners using the Bruce protocol fails in accurately predicting $\mathrm{VO}_{2}$ max in athletes aged 18-37 years, where only the regression models were moderately correlated with the $\mathrm{VO}_{2}$ max values obtained by ergospirometry.

Almeida et al. ${ }^{22}$ assessed the validity of the equation proposed by Cureton et al. ${ }^{23}\left(\mathrm{VO}_{2}\right.$ peak $=-8.41+0.34 * 2+$ 0.21 (agexgender) $-0.84(\mathrm{BMI})+108.94)$ ) for estimating the $\mathrm{VO}_{2}$ max of young Brazilians at a timed 1600-meter race, and suggest a prediction equation specific for this population. This study comprised 30 physically active male volunteers $(23 \pm 3.1$ years, $74.8 \pm 5.8 \mathrm{~kg}, 1.78 \pm 0.05 \mathrm{~m}$, $\left.49.8 \pm 6.5 \mathrm{~mL} \cdot \mathrm{kg}^{-1} \cdot \mathrm{min}-1\right)$ who underwent a maximal treadmill incremental test and a 1.600 -meter race different from those exercises used in our study. The individuals were divided into two groups: G1) for developing a prediction equation for $\mathrm{VO}_{2}$ max specific for young Brazilians; and G2) for analyzing the validities of both equations. The results showed statistically significant differences between $\mathrm{VO}_{2}$ max value directly obtained in the CPX $\left(50.1 \pm 7.1 \mathrm{~mL} \cdot \mathrm{kg}^{-1} \cdot \mathrm{min}^{-1}\right)$ and values estimated by the equation proposed by Cureton et al. ${ }^{23}\left(44.2 \pm 6.5 \mathrm{~mL} \cdot \mathrm{kg}^{-1} \cdot \mathrm{min}^{-1}\right)$, with a low correlation between them $(\mathrm{r}=0.21)$. The $\mathrm{VO}_{2} \max$ and running speed obtained in G1 lead to the following prediction equation: $\mathrm{VO}_{2} \max =0.177^{*} 1.600 \mathrm{Vm}(\mathrm{m} \cdot \mathrm{min}-1)+8,101$. When this new equation was applied to G2 participants, the estimated $\mathrm{VO}_{2} \max \left(50.1 \pm 7.2 \mathrm{~mL} \cdot \mathrm{kg}^{-1} \cdot \mathrm{min}^{-1}\right)$ was the same as that obtained by the gold standard $\left(50.1 \pm 7.1 \mathrm{~mL} \cdot \mathrm{kg}^{-1} \cdot \mathrm{min}^{-1}\right)$, with a high correlation between them $(r=0.81)$. The authors concluded that 
the equation proposed by Cureton et al. ${ }^{23}$ (based on the results of a North American sample) underestimated the $\mathrm{VO}_{2}$ max of physically active young Brazilians. The equation proposed in our study validly estimated the $\mathrm{VO}_{2}$ max for the 1600 - $\mathrm{m}$ performance test considering the studied population. However, the $\mathrm{VO}_{2}$ VAT and $\mathrm{VO}_{2}$ peak of healthy sedentary young people obtained from the direct method was not significantly different from those estimated by the prediction equation proposed by Cooper and Store ${ }^{19}$ considering the same population.

Lima and Abatti ${ }^{24}$ aimed to create a method capable of estimating the maximum $\mathrm{VO}_{2}$ during physical activity using basic physiological data (weight, BMI, height, age, $\mathrm{HR}$, and walking distance). For that, they used a study sample composed of 30 male young adults, apparently healthy, whose mean age was 23.4 years $( \pm 3.18$ years), mean height $1.78 \mathrm{~m}( \pm 0.06 \mathrm{~m})$, and mean weight $72.12 \mathrm{~kg}$ $( \pm 7.55 \mathrm{~kg})$. Absolute oxygen absorption per unit of time, $\mathrm{HF}$ at each moment of the test, and anthropometric data were collected, and $\mathrm{VO}_{2} \max (\mathrm{L} / \mathrm{min})$ values were plotted according to weight, BMI, age, and $\mathrm{HR}$ at various speeds. The factors that most influenced $\mathrm{VO}_{2}$ max were body weight (0.48) and BMI (0.42), although relatively distant from the unit, indicating a weak correlation. Considering that, the authors analyzed other parameters with higher correlation coefficients, and calculated the HRs for different speeds and different individuals for the absolute oxygen absorption per unit of time, reaching a mean linear correlation of $r=0.91$. Such coefficient indicates that an equation relating $\mathrm{HR}$ and $\mathrm{VO}_{2}$ max can be obtained for the various running speeds. Following Jackson et al. ${ }^{25}$, who employed BMI for creating a model capable of determining $\mathrm{VO}_{2}$ max, which was later modified by DF de Lima, who introduced BMI for estimating $\mathrm{VO}_{2} \max$ $\left(\mathrm{VO}_{2} \max (1 / \mathrm{min})=(0.02 \mathrm{BMI})+(-0.02595 \mathrm{age})+3.948\right)$, being a most precise and accurate prediction equation for representing this study group. Alternative methods for predicting $\mathrm{VO}_{2}$ max, independent from physical exercises, have been widely tested and proved to be highly reliable.

Studies employing methods similar from ours to assess healthy older adults and chronic $\mathrm{HF}$ patients are still scarce in the literature. In our study, the prediction equation proposed by Cooper et al. ${ }^{19}$ was unable to estimate $\mathrm{VO}_{2} \mathrm{VAT}$ and $\mathrm{VO}_{2}$ peak values for these populations, which may be justified by the fact that this equation considers only anthropometric values and load, regardless of individuals' health and age. A single predictive model will unlikely be able to properly measure the peak $\mathrm{VO}_{2}$ in all aspects, especially regarding the multiple indications and applications that it must necessarily attend. Our model aims not to be presented as the best, but rather as a simple, practical, and efficient alternative for reaching its goal.

Our study has some limitations: 1) Although data was collected at every breath, the gas analyzer supplied the data only every three breaths; 2) Patients with chronic HF were treated with beta-blockers and 3) The limited number of participants.

\section{CONCLUSION}

The prediction equation used in our study reached values similar to those obtained by the direct method performed in a cycle ergometer for $\mathrm{VO}_{2}$ at VAT and $\mathrm{VO}_{2}$ at exercise peak when applied in the YG. However, the prediction equation overestimated the values when compared to those obtained by CPX (gold standard) for the older group and for patients with chronic HF.

\section{Clinical application}

Considering the economic and technological obstacles for determining functional capacity, we inferred that mathematics would be a plausible way of overcoming these barriers. Therefore, we applied simple prediction equations that require more accessible variables and are much cheaper than the gold standard, besides being fast and applicable in a larger number of people, saving time and avoiding possible limitations pertinent to CPX administration in a cycle ergometer. This prediction equation may provide resources and open new horizons for researchers and clinicians.

\section{ACKNOWLEDGMENTS}

The authors would like to thank the Conselho Nacional de Desenvolvimento Científico e Tecnológico (CNPq) and the Fundação Carlos Chagas de Apoio à Pesquisa do Estado do Rio de Janeiro (FAPERJ) for funding this research from the Research Group in Cardiorespiratory Evaluated and Rehabilitation (GECARE).

\section{REFERENCES}

1. Neder JA, Nery LE. Fisiologia clínica do exercício: teoria e prática. São Paulo: Artes Médicas; 2003. 
2. Wasserman K, Hansen JE, Sue D, Whipp BJ, Casaburi R. Principles of exercise testing and interpretation. 3rd ed. Philadelphia: Williams \& Wilkins; 1999.

3. Balady GJ, Arena R, Sietsema K, Myers J, Coke L, Fletcher GF, et al. Clinician's guide to cardiopulmonary exercise testing in adults: a scientific statement from the American Heart Association. Circulation. 2010;122(2):191-225. doi: 10.1161/ CIR.0b013e3181e52e69

4. Powers SK, Howley E. Fisiologia do exercício: teoria e aplicação ao condicionamento e ao desempenho. 9th ed. São Paulo: Manole; 2000.

5. Meneghelo RS, Araújo CGS, Stein R, Mastrocolla LE, Albuquerque PF, Serra SM, et al. III Diretrizes da Sociedade Brasileira de Cardiologia sobre teste ergométrico. Arq Bras Cardiol. 2010;95 (5 Supl I):1-26. doi: 10.1590/S0066-782X2010000800001

6. Guyton AC, Hall JE. Tratado de fisiologia médica. Rio de Janeiro: Guanabara Koogan; 2006.

7. Agostoni P, Corrà U, Cattadori G, Veglia F, Battaia E, La Gioia R, et al. Prognostic value of indeterminable anaerobic threshold in heart failure. Circ Heart Fail. 2013;6(5):977-87. doi: 10.1161/ CIRCHEARTFAILURE.113.000471

8. American College of Sports Medicine. ACSM's guidelines for exercise testing and prescription. 7th ed. Philadelphia: Lippincott Williams \& Wilkins; 2006

9. Sociedade Brasileira de Cardiologia. I Consenso Nacional de Reabilitação Cardiovascular. Arq Bras Cardiol. 1997;69(4):267-91. doi: 10.1590/S0066-782X1997001000010

10. Glass S, Dweyr B, editors. ACSM's metabolic calculations handbook. Philadelphia: Lippincott Williams \& Wilkins; 2007.

11. Peterson MJ, Pieper CJ, Morey MC. Accuracy of VO2 (max) prediction equations in older adults. Med Sci Sports Exerc. 2003;35(1):145-9. doi: 10.1097/00005768-200301000-00022

12. Koutlianos N, Dimitros E, Metaxas T, Cansiz M, Deligiannis A, Kouidi E. Indirect estimation of VO2max in athletes by ACSM's equation: valid or not? Hippokratia. 2013;17(2):136-40.

13. Malek MH, Berger DE, Housh TJ, Coburn JW, Beck TW. Validity of VO2max equations for aerobically trained males and females. Med Sci Sports Exerc. 2004;36(8):1427-32. doi: 10.1249/ 01.mss.0000135795.60449.ce

14. Singh D, Agusti A, Anzueto A, Barnes PJ, Bourbeau J, Celli $B R$, et al. Global strategy for the diagnosis, management, and prevention of Chronic Obstructive Lung Disease: the GOLD science committee report 2019. Eur Respir J. 2019;53(5):1900164. doi: 10.1183/13993003.00164-2019
15. American Thoracic Society. Standards for the diagnosis and care of patients with chronic obstructive pulmonary disease. Am J Respir Crit Care Med. 1995;152(5 Pt 2):S77-121. doi: 10.1164/ajrccm/136.1.225

16. Knudson RJ, Lebowitz MD, Holberg CJ, Burrows B. Changes in the normal maximal expiratory flow-volume curve with growth and aging. Am Rev Respir Dis. 1983;127(6):725-34. doi: 10.1164/arrd.1983.127.6.725

17. Floriano RS, Orcini M, Reis MS. Importância do teste cardiopulmonar para a fisioterapia cardiovascular. Fisioter Bras. 2019;20(4):578-91. doi: 10.33233/fb.v20i4.2411

18. Gibbons RJ, Balady GJ, Bricker JT, Chaitman BR, Fletcher GF, Froelicher VF, et al. ACC/AHA 2002 guideline update for exercise testing: summary article. A report of the American College of Cardiology/American Heart Association task force on practice guidelines (Committee to Update the 1997 Exercise Testing Guidelines). J Am Coll Cardiol. 2002;40(8):1531-40. doi: 10.1016/s0735-1097(02)02164-2

19. Cooper CB, Storer TW. Teste ergonométrico: aplicações práticas e interpretação. São Paulo: Revinter; 2005.

20. Costa DC, Santi GL, Crescêncio JC, Seabra LP, Carvalho EE, Papa V, et al. Use of the Wasserman equation in optimization of the duration of the power ramp in a cardiopulmonary exercise test: a study of Brazilian men. Braz J Med Biol Res. 2015;48(12):1136-44. doi: 10.1590/1414-431×20154692

21. Debeaumont D, Tardif C, Folope V, Castres I, Lemaitre F, Tourny $C$, et al. A specific prediction equation is necessary to estimate peak oxygen uptake in obese patients with metabolic syndrome. J Endocrinol Invest. 2016;39(6):635-42. doi: 10.1007/s40618-015-0411-7

22. Almeida JA, Campbell EP, Sotero RC, Magalhães G, Simões HG. Validade de equações de predição em estimar o VO2max de brasileiros jovens a partir do desempenho em corrida de 1.600 m. Rev Bras Med Esporte. 2010;16(1):57-60. doi: 10.1590/ S1517-86922010000100011

23. Cureton KJ, Sloniger MA, O’Bannon JP, Black DM, McCormack WP. A generalized equation for prediction of VO2peak from 1-mile run/walk performance. Med Sci Sports Exerc. 1995;27(3):445-51.

24. Lima DF, Abatti PJ. Formulação de equação preditiva do Vo2max baseada em dados que independem de exercícios físicos. Semina Cienc Biol Saude. 2006;27(2):139-49. doi: 0.5433/1679-0367.2006v27n2p139

25. Jackson AS, Pollock ML, Ward A. Generalized equations for predicting body density of women. Med Sci Sports Exerc. 1980;12(3):175-81. doi: 10.1079/BJN19780152 